\title{
Ecotoxicity and Associated Threat of Polycyclic Aromatic Hydrocarbons (PAHs) to Biodiversity: A Review
}

\author{
I.U. ZUNGUM ${ }^{1 *}$, T.S. IMAM ${ }^{2}$ \\ ${ }^{* 1}$ Department of Biological Sciences, Federal University Gashua, P.M.B 1005, Yobe State- \\ Nigeria \\ ${ }^{2}$ Department of Biological Sciences, Bayero University Kano, P.M.B 1515, Kano State - \\ Nigeria
}

Corresponding email: idzungum@gmail.com

\begin{abstract}
There is a sustained rise in incidence of cancer and toxicity related to chemicals exerting enormous burden to public health and biodiversity. Polycyclic Aromatic Hydrocarbons (PAHs) are mong such contaminants, precisely the sixteen-priority characterized by United States Environmental Protection Agency (USEPA). Therefore, this review is aimed at further elaboration about the 16 USEPA characterized PAHs and threat portend to public health and biodiversity. PAHs are a class of very stable organic pollutants produced most commonly, by incomplete combustion of fossil fuel and are formed when complex organic substances are exposed to heat. PAHs in great amount due to build up over time by bioaccumulation can be perilous: to human beings of all age and levels, aquatic organisms, amphibians and reptiles.

The soil like the aquatic environment contains substantial quantity of PAHs since, atmospheric PAHs sediments on the soil due to dry and wet deposition, terrestrial organism are impacted if the soil is saturated with PAHs. Therefore, PAHs are a great source of trepidation for food safety, public health and biodiversity sustenance. Hence, tackling the spade of the menacing ubiquity of PAHs becomes necessary from its sources by encouragement of alternatives to petroleum fuels for machines and vehicles.
\end{abstract}

Keywords: Polycyclic Aromatic Hydrocarbons (PAHs), Ecotoxicity, Biodiversity, Public Health, Environmental safety.

\section{Introduction}

There is a sustained rise in incidence of cancer and toxicity related to chemicals exerting enormous burden to public health and biodiversity (Zungum et al., 2019; Yaya et al., 2019; Sarki and Roni, 2019). Therefore, this review is aimed at further elaboration about the 16 United States Environmental Protection Agency (USEPA) characterized PAHs and their threat to public health and biodiversity. Polycyclic aromatic hydrocarbons (PAHs) are a class of very stable organic pollutants produced most commonly, by incomplete combustion of fossil fuel and are formed when complex organic substances are exposed to heat plus generally, they do not occur as single compounds but as complex mixtures, (Mojiri, et al., 2019). PAHs represent a group of organic compounds which are highly soluble in organic solvents (lipophilic) but have relatively low solubility in water (hydrophobic) (ATSDR, 2009). They are pollutants that can be generated during processing food and are ubiquitous (Li et al., 2020). PAHs in the atmosphere can react with other pollutants such as sulphur dioxide, nitrogen oxides and ozone forming dinitro-PAHs, nitro-, diones, and sulfonic acids (Tran-Lam et al., 2018). PAHs may also be degraded by some microorganisms in the soil (Salman and Kadhim, 2018). PAHs also manifest various functions such as; conductivity, emission ability, light sensitivity, heat resistance, physiological actions, and corrosion resistance, they also possess very characteristic 
UV absorbance spectra, where each ring structure has a unique UV spectrum, thus each isomer has a different UV absorbance spectrum (Shimizu et al., 2020).

PAHs do not occur as single compounds but as complex mixtures in the environmental matrixes because of their related physicochemical properties during the pyrolytic process (Wolf, 2019). They get formed primarily during the incomplete heat induced decomposition of organic materials (Haritash \& Kaushik, 2009). The three environment sources of PAHs are: the petrogenic, the pyrogenic and biogenic. Pyrogenic PAHs are products of elevated temperature $\left(>690^{\circ} \mathrm{C}\right)$ and rapid oxygen depletion during an incomplete combustion of fossil fuels and organic substances (Zhao et al., 2017; Hailwood et al., 2001). Pyrogenic PAHs are creation resulting from the breakdown of organic matter to low molecular weight radicals during pyrolysis, which is subsequently accompanied by fast recombination into PAHs formation (Patel et al.,2020). Greater concentrations of Pyrogenic PAHs are normally found within the urban areas because their major sources are the incomplete combustion of petrol, gasoline and diesel in automobile, cum heat and power generation, production and use of coal tar and asphalt, and discharges from aluminium smelters and gas plants (Yang et al., 2021).

Biogenic PAHs are produced from biogenic precursors by plants, algae/phytoplankton, and microorganisms (Stogiannidis \& Laane, 2015). For example, concentrations of perylene, naphthalene, and phenanthrene concentrations have been found in hydromorphic soils, Magnolia flowers, and Coptotermes formosanus termite nests (Wolf, 2019). While, biogenic PAHs are often found at background levels in recent sediments, they are frequently the primary PAHs in older sediments deposited before increased industrialization (Lawal \& Fantke, 2017). Whereas, Petrogenic PAHs originates from biogenic processes at fairly low temperatures of about $100-300^{\circ} \mathrm{C}$ gradually over a long time, resulting in the materialization of petroleum and other fossil fuels comprising of Petrogenic PAHs (Lawal \& Fantke, 2017). These PAHs are ushered into the environment accidentally due to oil spills, discharge from tanker operations, and leakage of underground and aboveground storage tanks (Zakaria et al., 2002).

Evidently, ubiquity of PAHs makes it one of the most prevalent persistent organic pollutant in the environment such as water bodies, soil and in some organisms, but the ultimate reservoir is the soil (Huanling et al., 2019). Studies in the United Kingdom affirmed that more than 90\% of the PAHs resides in the surface of the soil (Wolf, 2019).

\section{Discussion}

\section{PAHs of Grave Concern (Sixteen USEPA Characterized)}

United States Environmental Protection Agency has classified sixteen PAHs as priority pollutants for human and animal toxicity as listed below: Acenaphthene, Acenaphthylene, Anthracene, Benzo(a)pyrene, Benzo(a)anthracene, Benzo(b)fluoranthene, Benzo(k)fluoranthene, Benzo(g,h,i)perylene, Chrysene, Dibenzo(a,h)anthracene, Fluoranthene, Fluorene, Naphthalene, Indeno(1,2,3-cd)pyrene, Phenanthrene and Pyrene (Wolf, 2019; Domingo, 2017; Hiba, 2015; Keith, 2015).

Acenaphthene appears as white needles: hydrophobic, lipophilic and produces pungent irritating smoke when exposed to heat. It is a natural constituent of coal tar and used in manufacture of pharmaceuticals, dyes, plastics, fungicides and insecticides (NCBI, 2019).

Acenaphthene can induce Cytochrome P450s and undergo oxidation to form toxic PAHs metabolite such as 1-Acenaphthenol which could be of toxic significance to both human and animals (Shimada et al., 2015). It irritates skin and mucous membranes in human (Kamata et al., 2018). Placed by IARC grouping in group 3, it was not classified as to its carcinogenicity 
potential in human (Kamata et al., 2018). Therefore, this PAH has not demonstrated any evidence to be considered carcinogenic to both human and animals (Smith \& Perfetti, 2019).

Acenaphthylene is a colourless crystalline solid present in petroleum products, coal and also found in automobile exhausts, cigarette, coal and wood emissions. It is used to make products for electronic engineering and in synthesis of fungicides, insecticides, dye and plastics stuffs (NCBI, 2019).

Acenaphthylene can induce Cytochrome P450s and undergo oxidation to form toxic PAHs metabolite such as 1-1, 2-Epoxyacenaphthene which could be of toxic significance to both human and animals (Shimada et al., 2015). It may affect autonomic nervous system, lungs, thorax, or respiration: respiratory depression; blood: haemorrhage and may cause damage and irritation to both eye and skin (NCBI, 2019).

Anthracene is yellowish white particle with mild aromatic odour and are commonly found in petroleum products, cigarette and coal smokes, automobile exhaust, and generated during other combustion and disposal of fossil fuels (Tay et al., 2017). Primarily, used as production of dyes, scintillation counter crystals, and smoke screens (NCBI, 2019). Despite, the substantial existent literature PAHs toxicity, there are very limited data on anthracene however, it is considered a mild irritant of the skin, nose, throat, and eyes (NIOSH, 2019). Though still considered an unverified carcinogen to human (IARC, 2018). But its commonly determined metabolite is trans-1, 2-dihydroxy-1, 2-dihydroanthracene (NCBI, 2019).

Benz[a]anthracene is a crystalline and appears as colourless powder which gives greenishyellow fluorescence, generated during and incomplete combustion of organic matter (NCBI, 2019). Primarily, it's found in automobile exhaust, coal tar, tobacco, petroleum and coal combustion emissions, cum open heat-treated foods (NCBI, 2019). Meanwhile, its Common metabolites are 3-hydroxybenzo [a] anthracene and 3,4-dihydroxy-1,2-epoxy-1,2,3,4tetrahydrobenz [a] anthracene (Guntupalli et al., 2019; Schmoldt et al., 1981). There is paucity in literature regarding other health effect in both human and animals. However, evidently its carcinogenic to both human and animals as it was shown to have caused cancer in lung and liver of animals (Siemiatycki \& Xu, 2019).

Benzo[a]pyrene appears in liquid state which is formed during a pyrolytic process of an organic substance and primarily, it's found in automobile exhaust, coal tar, tobacco, petroleum and coal combustion emissions, cum during pyrolysis of foods (NCBI, 2019). Its popularly for various irritation and other mild health challenge to human and animals (SEPA, 2019). And this substance has been designated as a biomarker for the monitoring PAHs movement and toxicity to both human and animals due its toxicity potential and prevalence (Ince \& Ince, 2019). 3, 4Benzpyrene is one of its major metabolites produced when cytochrome P450 is induced and it is carcinogenic to both human and animals (IARC, 2019).

Benzo[b]fluoranthene appears as needles or yellow fluffy powder, formed during a pyrolytic process of an organic substance and primarily, it's found in automobile exhaust, coal tar, tobacco, petroleum and coal combustion emissions, cum during pyrolysis of foods pyrolysis products (NCBI, 2019). On a direct contact or smokes causes irritation of the skin, throat and bronchial tubes (Pohanish, 2012). Benzo(b)fluoranthene is a human and animal carcinogen (IARC, 2019).

Benzo[ghi]perylene is a colourless crystalline solid, generated in the incomplete pyrolysis of organic substances and fossil materials. Benzo[ghi]perylene 3,4-oxide and Benzo[ghi]perylene 3,4,11,12-bisoxide are the major metabolites of benzo[ghi]perylene which targets, lungs, skin, eyes and sperm and affects their integrity (NCBI, 2019; Jeng et al, 2013). In flames, it produces 
acrid, corrosive, irritating and toxic fumes while, in liquid state emits suffocating and dizziness causing vapour (ERG, 2016). Benzo[g,h,i]perylene is a human carcinogen (IARC, 2019).

Benzo(k)fluoranthene appears as pale-yellow needles or yellow crystalline solid and is generated during organic matter combustion. Benzo(k)fluoranthene is primarily located in automobile exhaust, cigarette, coal, coal tar and oil combustion discharges (NCBI, 2019). The compound 8,9dihydoxybenzo(k)fluoranthene is the major metabolite when induced by CP450 enzymes (LaVoie et al., 1980). Meanwhile, the major toxicological effect of concern is its possible carcinogenicity to humans (NCBI, 2019).

Chrysene is a white crystalline substance and among the PAH4 biomarkers of monitoring of toxicity and movement of PAHs and the major metabolites that induces Cytochrome $4501 \mathrm{~A}$ enzyme are chrysene-3,6-diphenol, 1-hydroxy chrysene and 6-hydroxychrysene (Lou et al., 2019; NCBI, 2019). It is associated with cancer in both human and animals (IARC, 2019).

Dibenzo[a,h]anthracene is a crystalline, generated from pyrolytic process of organic matter and primarily located automobile exhaust, heat treated foods and fossil deposits (NCBI, 2019). The major is for purpose of research to induce tumour in animals. These are the major metabolites are 1,2dihydro-1,2dihydroxydibenzanthracene and 3,4dihydro3,4dihydroxydibenz anthracene. Dibenzo(a,h)anthracene is a mutagenic and carcinogenic to both human and animals (NCBI, 2019).

Fluoranthene appears as light-yellow fine crystals with no evidence of animal or human carcinogenicity (NCBI, 2019). Commonly, Its Metabolites are 9-fluorenone and 9hydroxyfluorene (Sepic et al., 2003).

Fluorene is a whitish and generated during incomplete combustion of organic substances and its commonest metabolite is 2-OH fluorine (Peiffer et al., 2013). Causes corrosion/irritation and respiratory tract irritation but there is absent of available data about its association with cancer (NCBI, 2019).

Indeno[1,2,3-cd]pyrene

Indeno [1,2,3-cd] pyrene is yellowish in colour, generated from burning of fossil fuel and during incomplete combustion and sourced primarily from fossil deposits (NCBI, 2019). The compound 8-Hydroxyindeno [1,2,3-cd]Pyrene is its most common metabolite (Rice et al., 1986). Indeno[1,2,3-cd]pyrene is carcinogenic to human (IARC, 2019).

Naphthalene is white and a volatile, solid which emits strong mothball odour in contact with flames. Sourced from fossil deposit and generated from incomplete combustion, and is used to synthesis phthalic anhydride and also as a repellent of moth (NCBI, 2019). The major Metabolites are 1, 2 dihydronaphthalene- 1,2-diol, 1, 2-dihydro-1-napthol (Parke, 1968). Health challenges associated to Naphthalene are cataracts, haemolytic-anaemia, retinahaemorrhage, liver and neurological system damage (NCBI, 2019). It is connected to colorectal and laryngeal cancer and it is a human carcinogen (NCBI, 2019).

Phenanthrene appears as colourless crystals with faint odour and with the following metabolites: trans1,2-dihydro1,2-dihydroxyphenanthrene, trans-3,4-dihydro3,4-dihydroxy phenanthrene and 4-hydroxyphenanthrene (Lou et al., 2019; Rossella et al., 2009). On exposure to Phenanthrene the following symptoms will be exhibited: skin irritation, respiratory irritation, dermatitis, cough, bronchitis, respiratory neoplasm, dyspnoea and kidney neoplasm (NTP, 1992). Shows no evidence of associated cancer risk to both human and animals (IARC, 2019). 
Pyrene a colourless solid crystal and its major metabolite is 1-hydroxypyrene (Beach et al., 2010). Can cause respiratory, skin and eye irritation, (NCBI, 2019). 1-hydroxypyrene is its metabolites (Rossella et al., 2009). No sufficient data with regards to its carcinogenicity (IARC, 2019).

\section{Occurrence of PAHs in Food}

Food is a necessity for survival and nourishment of all living organism of which without they seize to exist. Protein component of the food like meat are very popular in low-income communities across the world, where it is served during festivities in abundance (Zungum et al., 2020). However, many studies in recent years have shown that the second major PAHs exposure route is through consumption of food (Zhu et al., 2021; Babic et al., 2018; Duan et al., 2016; Xia et al., 2010). Although, contamination of food by these pollutants is chiefly constraints on: type of fuel applied such as fuel wood, scrape tyre, liquefied petroleum gas, and kerosene. Also, processing procedures adopted: cooking, smoking, grilling, frying, roasting and singeing. Equally, it is dependent on the distance from source of PAHs contamination such as coal mine or volcanic eruption sites, oil spill locations, chemical industrial waste channels or dump sites (Eze et al., 2019). And, even nearness to traffic junctions with lots of automobile exhaust emissions (Tella et al., 2017). According to Abu (2013) there are other mechanisms that result in the generation of PAHs such as pyrolysis of animal fats. Eze et al. (2019) in agreement, reported that PAHs are formed when juice and fat of grilled meat and fish placed over naked flames which generates PAHs that adheres to the surface of the meat, fish and other food substances processed.

Over the past 20 years, there are thousands of studies on PAHs in food and persistently raising germane alarms about the toxic potential, transport and fate of metabolites of PAHs within the environment and bodies of organisms (Sun et al., 2019). Meanwhile, several of such studies confirmed the presence of PAHs in food products processed by various methods aforementioned as related by Zachara et al. (2017) that PAHs were determine in commercially smoked fish and meat smoked meat and fish products from polish markets. PAHs were also determined in grilled meat by Kamankesh et al. (2015). Also, determined in smoked fish by Ghasemzadeh-mohmmadi et al. (2012). Equally, was observed in smoked products by Ledesma et al. (2015). And in meat smoked with deferent kinds of smoking spices and wood by Hitzel et al. (2013). In Similar vein, it was noticed in Swedish smoked fish and meat (Wretling et al., 2010). PAHs in smoked ham at households in Serbia as reported by Kartalovic et al., (2015). Also, PAHs content were seen in smoked common carp meat in Serbia (Babić et al., 2017). PAHs were noticed in smoked duck in china (Chen \& Lin, 1997). Studies in Doha, Qatar showed after analysing smoked meat samples, there were none that exceeded European Commission's maximum limits, EC 835/2011 (Hussain et al., 2018). However, similar research undertaken by Tran-Lam et al. (2018) in Vietnam revealed thus:

the ranges of average PAHs levels were 9.3-9.6 $\mu \mathrm{g} / \mathrm{kg}$ (for instant noodles), $0.22-2.48 \mu \mathrm{g} / \mathrm{kg}$ (for cakes) $0.91-4.83 \mu \mathrm{g} / \mathrm{kg}$ (dried vegetables), $5.14-23.32 \mu \mathrm{g} / \mathrm{kg}$ (teas), $4.82-24.35 \mu \mathrm{g} / \mathrm{kg}$ (coffees), and $1.43-25.2 \mu \mathrm{g} / \mathrm{kg}$ (grilled meats). The results indicated that the total concentrations of residual PAHs and benzo(a)pyrene in the instant noodles and grilled meat samples surpassed the maximum limits tolerated by the European Commission $(35 \mu \mathrm{g} / \mathrm{kg}$ and $5 \mu \mathrm{g} / \mathrm{kg}$, respectively) in many investigated samples.

PAHs in substantial quantity was seen in smoked fish and meat across Finland according to Mirja et al., (2018). In similar cases, PAHs occurrence was established in chocolate candies, tea, milk, toasted bread and flour (Hiba, 2018). In consistence with other studies across the world, PAHs manifestation was confirmed in arrays of consumables across Africa such as; smoked Bush meats in Kumasi, Ghana and was revealed to have contained PAHs below the 
EU peg limits for smoked meats, this is according to Abu, (2013). In a related work the 16 priority PAHs were detected in smoked Tilapia Fish and Catfish, revealed through a research conducted by Nnaji \& Ekwe, (2018). They were equally, report in smoked cephalopods, crustaceans, bivalve molluscs, and baby foods (Ijeoma et al., 2015a). The presence of PAHs was also established in roasted and smoked fishes, meats, corn, yam and ripe plantain in Eastern Nigeria (Eze et al., 2019). PAHs were seen in grilled fish and meat, smoked fish and roasted yam in Lagos and Ogun states of Nigeria (Oranusi et al., 2018). Rubber tyres singed cattle hides indicate dangerous deposition of high levels of PAHs in Abia State, Nigeria as disclosed in a research undertaken by Nnaji et al. (2017). Ijeoma et al. (2015b) confirmed the presence of PAHs in barbecued charcoal grilled meat and singed cowhide in Umuahia, Abia state, Nigeria.

\section{Ecotoxicity Effects of PAHs}

The toxicity credited to PAHs is rampant and can be observed across all ecological systems including: aquatic and terrestrial realms. Sequel to the far-reaching voluminous research in area of PAHs toxicity, Agency for Toxic Substances and Diseases Registry (ATSDR) ranked them $9^{\text {th }}$ on their Substance Priority List (SPL) based on their potential for combine toxicity, frequency and exposure to human (ATSDR, 2017). Correspondingly, The International Agency for research on Cancer (IARC) has classified PAHs into categories based on impending capacity for carcinogenicity: group 1, 2A,2B, 3... As known, probable, possible, and nonclassified human carcinogen. Of these, the 16 USEPA prioritized PAHs were all fitted in to the categories: group 1, Benzo(a)pyrene; group 2A, Dibenzo(a,h)anthracene; group 2B, Chrysene, Benzo(a)anthracene, Benzo(b)fluoranthene, Benzo(k)fluoranthene, Naphthalene, Indeno(1,2,3-cd)pyrene; and group 3, Acenaphthene, Acenaphthylene, Anthracene, Benzo(g,h,i)pyreline, Fluoranthene, Fluorene, Phenanthrene and pyrene (IARC, 2019; 2010).

\section{PAHs Toxicity in Human}

PAHs in great amount due to build up over time by bioaccumulation can be dangerous to human beings capable of damaging body cells. They are associated with carcinogenicity, mutagenicity, teratogenicity, genotoxicity, and other related toxin induced complications in human (NCBI, 2019). Historically, PAHs toxicity was first reported by Sir Percival Pott in the year 1775, initially noticed an associated progression of cases of scrotal cancer among workers consistently exposed to chimney sweeps and soot (Pott, 1775). Subsequently, to date tonnes of PAHs examination has reported exposure and cancer incidence to both human and animals (ARTDR, 2015, Kim et al., 2013; Silverman et al., 2012; IARC, 2010; Zhang et al., 2009; Bosetti et al., 2007; ATSDR, 1995). However, there are only limited epidemiological reports of incidence of lone PAHs exposure to human but of their activity in groups (Sasikumar et al., 2018). Conversely, numerous researches from experimental animals were subjected to tests with Benzo(a)pyrene: ingested via gastro intestinal track, inhaled via respiratory track and exposed to dermal contact, all repeatedly kept leading to tumour, cancer and mutation (IARC, 2019 ; 2012). Of recent, food and occupational exposure to materials contaminated with PAHs have become leading sources of concern associated for cancer (IARC, 2019; 2010).

PAHs can extensively spread all through human body parts, as investigation has confirmed the distribution in several studies and especially lodged in Adipose tissues due to being lipophilic in nature (Abdel-shafy \& Mansour, 2016). Once been in the body, they induce cytochrome 450 la enzyme triggering the Cytochrome450-PAHs-oxidase-pathway (Fakolade et al., 2017). This very metabolic pathway changes the PAHs to intermediate of polar epoxide and further transformed to Phenol and derivatives of dihydrodiol and lastly converted to sulphate and glucuronide conjugates and then excreted into urine and bile (Campo et al., 2010). 
However, the conversional metabolism could lead to bio-activation of PAHs toxicity potency resulting in the materialization of electrophiles or metabolites which causes human health challenges (Gelboin, 1980). Evidently, for this reason PAHs are known as pro-carcinogen since they are harmless in their pristine state but require a metabolite to activate the toxicity potential to cause: carcinogenicity, DNA damage, mutagenic effect or genotoxicity (Moorthy et al., 2015). Furthermore, there exist three pathways for the activation of PAHs carcinogenic potency: radical cations pathway, o-quinone pathway and bay-region dihydrodiol epoxide pathway. This pathway leads to synthesis of radical cations, redox-active-o-quinone, electrophiles and diol epoxides which reacts with DNA to form DNA-adducts (Zhang et al., 2012a).

Impact of PAHs on the immune system has been studied extensively and reported its severity on human and animals (Ulieme et al 2019). The immune suppression as the major and most disturbing effect of PAHs was confirmed in series of investigations over the years, and revealed thus, the route of exposure is immaterial as the end effect exerted is systemic disruption (IPCS, 2010). Hence, PAHs induced immune suppression always associated to increase in susceptibility of an individual organism to infectious diseases, cancer of various kind and mortality (Abdel-shafy \& Mansour, 2016). More elaborately, immune system potentiation is associated to increased immune cell synthesis of cytokines with a resultant inflammation. Consequently, facilitating expression of hypersensitivity, allergic responses, auto-immunity and tumour development (Rodelli et al., 2016).

The literature bank concerning PAHs and immune system relation claim that the most prevalent and far-reaching effect of PAHs to human and animal systems is immune suppression (Parvez et al., 2019). Additionally, data from the literature confirmed that frequent reported route of exposure in vitro as atmospheric and dietary (Burchiel \& Luster, 2001). Whereas, route of exposure in vivo as inhalation and injection into sub-cutaneous and intra-peritoneal (Pessa et al., 2001). In addition, studies have reported immune toxicity resulting from oral consumption of food (Fakolade et al., 2017). Furthermore, the severing of the immune system due to buildup of PAHs caused DNA-Adducts in several organs of the body and resulted in cancer (Ulieme et al., 2019).

\section{Teratogenicity}

Effects due to embryotoxicity of PAHs have been confirmed from a number of experiments on exposure to PAHs mixture (Perera et al., 2005; Wassenberg \& Di-Giulio, 2004). Investigation showed that ingestion during pregnancy of substantial quantity of PAHs in food resulted in low baby weight and birth defects (Fakolade et al., 2017). Similarly, it was confirmed to that exposure to PAHs through several route during pregnancy result in birth complications such as: premature delivery, low birth weight and cardiac abnormalities (Edwards et al., 2010). Further, children given birth to in towns contaminated with PAHs like Teplice were reported to have developed multiple health challenges including: growth retardation, respiratory malfunctions and stunted intra-uterine growth (Pratt et al., 2011). Research further demonstrated that PAHs exposure led to the liver inflammation that resulted in cirrhosis (Ulieme et al., 2019). In addition, PAHs was established in prenatal exposure causing behavioural problems, lowering in IQ, Asthma and DNA adduct that resulted in cancer (Drwal et al., 2019).

\section{PAHs Acute Health Effects}

The consequence of PAHs contamination in human could be based on the route of contact, quantity and toxicity potency of the PAHs in exposed to (ACGIH, 2005). Many other factors could be responsible for health induced impact due to PAHs including: pre-existing health status and age (Abdel-shafy \& Mansour, 2016). The presence of PAHs was confirmed from 
different biological samples of human such as: blood, urine, serum, plasma, saliva, breath exhaled, breast milk, placenta and cerebrospinal fluid (Santos et al., 2019). The tendency of PAHs to induced short time health complications in human has been reported resulting in symptoms such as: skin and eye irritation, nausea, vomiting, headache, diarrhoea, allergic reactions, confusion and diaphoresis (ATSDR, 2013; IPCS; Unwin et al., 2006). Though, the priority PAHs mixtures most times, act in unison that its unlikely to identify which one acted or not (Hiba).

\section{PAHs Chronic Health Effects}

There is paucity of literature regarding human chronic effects due to PAHs toxicity. However, long term exposure that resulted in health complication as earlier captured leads to immune suppression, eyes defect endocrine disruption, kidney, lung and liver damage (Kuppusamy et al., 2020; IARC, 2019). Equally, sustained skin contact may induce inflammations and withstood ingestion and inhalation can permit breakdown of red blood cells (NCBI, 2019). Essentially, route of exposure, quantity and prolonged exposure increases the susceptibility to chronic health complications that eventually ends in fatality (Diggs et al., 2011). Meanwhile, bioaccumulation is observed due to protracted PAHs interaction to human and animal body systems and consequentially, deepening the impairment and enhance the susceptible to cancer especially to urban dwelling population by $(10.7 \%)$ ten percent in a long run (Zhu et al., 2019). Plus, copious investigations implicated the sixteen priority PAHs of being the culprit behind the formation of DNA-adducts due to unrelenting exposure in several human body tissues such as: cervix, vulva, oesophagus, bone marrow, prostate and placenta (Rondelli et al., 2016). Further, degenerating to more complications including: teratogenicity, genotoxicity, mutagenicity and carcinogenicity in human of all age brackets (ATSDR, 2013).

\section{PAHs in Aquatic Organisms}

\section{Pisces}

Aquatic organisms were reported to be impacted by the toxicity of Poly aromatic hydrocarbon at the detriment of various units of the ecosystem. Aquatic environment was believed to be most susceptible to different sources of PAHs pollutants in contrast to other media owing to been an important basin for most noxious chemicals (Copat et al., 2018; Ferrante et al., 2018). PAHs was found in several species of fishes within the Persian Gulf contaminated due to oil spill (Akhbarizader et al., 2019). Correspondingly, another research on histopathological examination of Tilapia fish was made for liver, gills, kidney, male gonad and female gonad. Liver showed congestion of blood vessels and hepatic sinusoids with focal necrotic changes of hepatocytes, Gills showed congestion of blood vessels, hyperplasia and adhesion of secondary gill lamellae, Kidney showed congestion of blood vessels and degeneration of renal tubules, Male gonad showed degeneration and necrosis of some seminiferous tubules, oedema and severe reduction in all spermatogenic stages and degeneration and Female gonad showed severe necrosis of developmental stages of oocytes along with degenerated mature ripped oocytes in crude oil contaminated water, treated fish (Dighiesh et al., 2019). In a similar work, Vignet et al. (2016) reported inhibition of spermatogenesis, germ cell degeneration, seminiferous tubular epithelial degeneration and necrosis as observed in Oreochromis niloticus, Synodoniis schall and Tilapia zillii after taken from a PAHs contaminated water of El Salam Canal. Cardiotoxicity is one of the most common effects observed in many teleost species after a developmental exposure to PAHs (Madison et al., 2015). PAHs Exposure has been well established to disrupt or impair the natural function of endocrine systems in teleost (Dey et al., 2019; Alsaadi et al., 2018). Similarly, PAHs were discovered to activate Cytochrome P450-1A, a gene up-regulator of toxins and by induction of the aryl hydrocarbon receptor and were established to be responsible for teratogenic effects and embryonic cardiac deformities on exposed killifish embryos (Volkoff et al., 2019). In addition, Grung et al., 2016 
documented PAHs exposure to Eurasian minnow (Phoxinus phoxinus) where activation of cytochrome 450 A1 was observed, DNA adduct and PAHs metabolites formation seen. The genotoxic potency of PAHs was confirmed in an in vitro study where Zebrafish embryos were exposed PAHs (Mccarrick et al., 2019). A study adduced that bioaccumulation was the primary process that controls pollutants aggregation in aquatic organisms (Akhbarizadeh et al., 2019). In conformity with the findings Finch \& Stubblefield, (2019) relates that PAHs being sufficiently lipophilic bioaccumulates into tissues and interferes with normal system functions of these organisms.

\section{PAHs in Other Aquatic Organisms}

Toxicity reports from many previous researches also reveal the noxiousness related to Poly aromatic hydrocarbon in a test where amphipods taken from southern European waters and subjected to series of toxicity assessments in the laboratory: the amphipods die due to multiple complication resulting from PAHs mixture toxicity (Sanz-Lázaro, 2008). In another research by Zychowski \& Godard-Codding (2017) who, narrated that European pond turtle and Caspian turtles were picked from industrial waste water plants and oil spilled contaminated waters in Azerbaijan and reported to have recorded high presence of PAHs which subsequently lead to varieties of adverse effects, skin sloughing, hyperkeratosis, necrosis, acanthosis, mutagenicity, DNA and chromosomal damage, and genotoxicity. Other studies observed mutagenicity and damage to DNA in Dragon fly Nymph (Odonata anisoptera) due to PAHs in artificial and natural aquatic environments (Meland et al., 2019). Studies also identify presence and toxicity resulting from PAHs in mollusc and eel (Sun et al., 2018). PAHs was detected in numerous tissue and organs of prawns and crabs isolated from oil waste waters of Persian Gulf (Akhbarizadeh et al., 2019). Equally, PAHs was seen to have caused toxicity to crabs (Callinectes pallidus) isolated from Niger Delta creek, Nigeria (Erema \& Adaobi, 2013). Similar, an investigation undertaken in Persian Gulf waste confirmed that among benthic species studied, including; Epinephelus coioides, Penaeus indicus, Liza klunzingeri, Panaeus semisulcatus, and Portunus armatus and those that are less motile were more vulnerable to PAHs contaminants accumulation and better candidate species for monitoring aquatic environments (Akhbarizadeh et al., 2019).

\section{PAHs in Amphibians}

All known amphibians have highly permeable membranes to facilitate the exchange of nutrients and gases with the water column. Membrane permeability increases the occurrence of aquatic xenobiotic ingestion and thus toxicity. Most Amphibians are omnivores, consuming algae, macrophytes, detritus and small invertebrates, which may also act as a dietary source of aquatic contaminants resulting in bioaccumulation (Patterson, 2019). Tadpoles and frogs are common Amphibians and are sources of prey in most aquatic ecosystems, fish often target adult frogs as a favoured food source and this interaction may introduce contaminants to trophic webs and eventually human consumers (Patterson, 2019). Amphibian species experience cardiotoxicity on developmental exposures, but predictions of severity and sensitivity are complicated due to large inter-species differences among amphibians and a lack of precedent setting work conducted (Alderman et al., 2017). Exposure to PAHs have been well demonstrated to disrupt or impair the normal function of endocrine systems in amphibians; thyroid hormone receptor beta (TRB) expression was highly affected by PAHs exposure in amphibians (Alderman et al., 2018; Alsaadi et al., 2018). Alterations in metamorphosis timelines and developmental outcomes occur in L. sylvaticus raised in reclaimed wetlands contaminated with PAHs (Products et al., 2011; Whyte et al., 2000). The normal activity of the hypothalamus-pituitary-thyroid (HPT) axis is 
essential for reproduction, development and growth of amphibians, but is disrupted by exposure to PAHs (Alderman et al., 2018). Exposure to certain PAHs including naphthalene can disrupt the normal gas exchange mechanism in amphibian integument, leading to decreased $\mathrm{CO}_{2}$ excretion rates, and potentially to asphyxiation (Wallace et al., 2018). Disruptions in gas exchange can impair fitness or survival if respiration is sufficiently impaired. PAHs exposure resulted in the disruption of normal steroid biosynthesis pathways and metabolic disorder related pathways in amphibians (Lara-jacobo et al., 2019). Steroidal pathways are critical for the formation of hormones that regulate the bodies' endocrine systems and homeostasis. Even low concentrations of PAHs can cause teratogenicity to amphibian embryos, and tadpoles that survived the PAHs exposures displayed behavioural and morphological abnormalities such as twisted spines and irregular swimming patterns indicating chronic, sub-lethal effects from embryonic PAHs exposures (Campbell et al., 2019). The jelly coating around amphibians' eggs, known as the extra-cellular matrix confers protection against the embryonic exposure of PAHs, acting as a sequestering agent to shield the embryos (Parrott et al., 2018). The targeted organ accumulation and toxicity is typically localized to the kidneys and liver, and compounds such as $\mathrm{B}(\mathrm{a}) \mathrm{P}$ cause metabolic and transcriptomic toxicity and carcinogenicity in amphibian hepatocytes (Lara-jacobo et al., 2019; Harner et al., 2018). This data provides evidence that PAHs and other similar AhR antagonists in crude oil may lead to adverse biological responses in developing amphibians either through mechanisms of increased genotoxicity, narcosis or disrupted endocrine signalling (Campbell et al., 2019). In addition, high mortality of Amphibians living in PAHs contaminated sediment ponds was documented (Johansen, 2013).

\section{PAHs in Terrestrial Organism}

The soil contains substantial quantity of PAHs since, atmospheric PAHs sediments on the soil due to dry and wet deposition, terrestrial organism are impacted if the soil is saturated with PAHs which could cause mild to adverse effects and in some cases tumour and cancers (Beyer, 2010). Mammal have been reported to ingest PAHs in food or inhaled from polluted air (Dong et al., 2012). Plants also, uptake PAHs from soil though their roots and translocate them to other parts of the plants to be stored, factors governing the uptake are physicochemical potential of the plant, water solubility, concentration and hormone (Abdel-shafy and Mansour, 2018). There limited literature on PAHs induced phytoxicity (Beyer et al., 2010). Some plants provide resistance and protection against PAHs whereas, other plants synthesis PAHs to serve as growth hormone (Abdel-shafy \& Mansour, 2018).

\section{PAHs Toxicity in Reptiles}

Polycyclic aromatic hydrocarbons and other pollutants have been identified as major contributors to receding factor for reptilian population and as contributors to toxicity reported from number of studies (Zychowski \& Godard-Codding, 2017; Sparling et al., 2010; Gibbons et al., 2000). These toxicity effects are many including: hatching and other reproductive difficulties, feeding and digestive abnormalities, endocrine disruption, immune system suppression, mutagenicity and cancers (Sparling et al., 2010; Van Meter et al., 2006; Aguirre and Lutz, 2004; Romero and Wikelski, 2002; Wikelski et al., 2001; Gibbons et al., 2000; Gibbons et al., 2000; Crain \& Guillette, 1998; Vonier et al., 1996; Hutchinson \& Simmonds, 1992). Despite the relatively scarce literature regarding ecotoxicological effects due to PAHs, it has been found to interfere with feeding habits, sex determination, egg size, embryonic development and increased burden of accumulation within body parts, and are associated to global reptilian decline (Zychowski \& Godard-Codding, 2017; Smith et al., 2007; Hopkins, 2000). Studies on desert lizard (Acanthodactylus scutellatus) taken contaminated oil spill sites further revealed that PAHs were found to have exerted ecotoxicological effects in all aspects of the organism's normal physiological functions including cases of cancers (Al-Hashem et al., 2007). Similarly, the lizard, Pordarcis sicula was found with extremely high PAHs 
concentration has been enzymically distorted and with severed physiological functions (Zychowski \& Godard-Codding, 2017).

\section{Crocodile}

There only few studies that documented findings of PAHs ecotoxicological significance, of these all concentrated on the captive crocodile Crocodylus niloticus (Arukwe et al., 2016). The study investigated oxidative stress responses finding that severity of PAHs contamination is sex dependent, and PAHs is carcinogenic to the crocodiles (Arukwe et al., 2015). And that is immune suppressant, endocrine disrupting and instrumental to reproductive abnormalities and infantile related deformitie (Arukwe et al., 2016).

\section{Snake}

Like other reptiles, there are few researches that attempted to address PAHs exposure in snakes and the earliest investigations focused on control of exposure then subsequently, enzymatic activities, particularly in Thamnophis species and Elaphe guttatta (Bani et al., 1998; Scwen \& Mannering, 1982). The species were particularly important for biomonitoring of toxicity in snakes (Zychowski \& Godard-Codding, 2017). In a separate investigation, PAHs was seen in the shed skin of Elaphe guttatta when he had eaten PAHs contaminated mice and further reports biomagnification of PAHs along the food chain (Jones et al., 2009). PAHs were discovered in several body parts of Aquatic snakes: Lapemis curtus and Hydrophis cyanocinctus taken from crude oil contaminated area along the Persian Gulf (Soltani et al., 2019). Petrogenic sources of the PAHs contributes significantly to the exposure of snakes to the contaminant (Sereshk \& Bakhtiari, 2014). Also, studies explored the exposure and toxicity of PAHs from aquatic snakes in Goa, India such that it was found in Kidney, liver and guts (Mote et al., 2015).

\section{PAHs Toxicity in Rodents}

Experimental data available in vivo on the prenatal developmental toxicity potency of toxic substances showed that some PAHs were confirmed to induce Prenatal developmental toxicity in experimental animals such as mice (Kamelia et al., 2019a; Feuston, 1989;1996; 1997; Hoberman, 1995). The data generated from in vivo investigations are in consistent to that of in vivo recent findings in rodents (Kamelia et al., 2019a). Where PAHs content, induced Prenatal developmental toxicity, as quantified in the embryonic stem cells, this further inferring potency for genotoxicity (Kamelia et al., 2017). Further studies, confirmed activation of the aryl hydrocarbon receptor (AhR) from in vitro exposure of mouse embryonic stem cell to PAHs (Kamelia et al., 2019b).

PAHs was equally associated to mutagenicity as was confirmed in in vitro research where they were found to induce DNA methylation, and reproductive toxicity in rats with consequential infertility, immune suppression, neurotic and pancreatic secretion abnormalities (Zhang et al., 2018). PAHs also damage selectively endocrine glands and targets hormones in female rodents (Kamelia et al., 2018). PAHs compounds depress synthesis of DNA in ileum and spleen and severely injure ovary and elicit ovarian tumours, leukaemia and causes adrenal apoplexy (Uematsu \& Huggins, 1968). It also elicits DNA adduct formation and apoptosis further resulting in tumour and carcinogenicity of the rat liver (Trilecová et al., 2011). Recent research also affirmed that PAHs exposure leads to hepatic inflammation and apoptosis, and increase in susceptibility to diabetes type 2 and other related abnormalities (Ulieme et al., 2019).

\section{Conclusion}

The sustained exposure to PAHs could lead to extinction of some organisms dwelling in contaminated environment. And, if unchecked, the extant open-fire-food processing method could seamlessly increase the prevailing food safety challenges and general public health 
concerns. Therefore, the 16 USEPA characterized PAHs are a great threat to food safety, public health and biodiversity.

\section{Recommendations}

1. The use of solar and other clean energy sources should be encouraged to cut down emission of PAHs from petroleum driven vehicles.

2. To avoid biodiversity lost; oil spills need to be tackled expediently without any unnecessary delays and infected organisms due PAHs contamination should be isolated to avoid breeding mutants.

3. To cut-down health costs; the authorities in developing countries ought to be religiously serious in enforcing the band in use of scrap tyre and petroleum derived fuels to process foods in an open-fire.

\section{Conflicts of Interest}

The authors declare no conflict of interest.

\section{Funding}

This research received no external funding.

\section{Reference}

Abdel-Shafy, H. I. and Mansour, M. S. M. (2016). A Review on Polycyclic Aromatic Hydrocarbons: Source, Environmental Impact, Effect on Human Health and Remediation. Egyptian Journal of Petroleum, 25: 107-123. DOI: http://dx.doi. org/10.1016/j.ejpe.2015.03.011.

Abu, (2013). Determination of Polycyclic Aromatic Hydrocarbons in Smoked Bush Meat, (Master' degree dissertation). Kwame Nkrumah University of Science and Technology, Kumasi, Ghana. Retrieved from http://dspace.knust.edu. gh/handle/123456789/6175.

ACGIH (American Conference of Governmental Industrial Hygienists), (2005). Polycyclic Aromatic Hydrocarbons (PAHs) Biologic Exposure Indices (BEI) Cincinnati. OH: American Conference of Governmental Industrial Hygienists. Retrieved from http:// www.atsdr.cdc.gov/t oxprofiles/tp69.pdf.

Akhbarizadeh, R., Moore, F. and Keshavarzi, B. (2019). Polycyclic Aromatic Hydrocarbons and Potentially Toxic Elements in Seafood from The Persian Gulf: Presence, Trophic Transfer, And Chronic Intake Risk Assessment. Environ. Geochem. Health, V (0123456789). https://doi.org/10.1007/s10653-0 19-00343-1(0123456789).

Alderman, S. L., Lin, F., Farrell, A. P., Kennedy, C. J. and Gillis, T. E. (2017). Effects of diluted bitumen exposure on juvenile sockeye salmon: From cells to performance. Environment and Toxicological Chemistry, 36: 354-360.

Alderman, S. L., Lin, F., Gillis, T. E., Farrell, A. P. and Kennedy, C. J. (2018). Developmental and Latent Effects of Diluted Bitumen Exposure on Early Life Stages of Sockeye Salmon (Oncorhynchus Nerka). Aquatic Toxicology, 202:6-15.

Alsaadi, F. M., Madison, B. N., Brown, R. S., Hodson, P. V. and Langlois, V. S. (2018). Morphological and Molecular Effects of Two Diluted Bitumens on Developing Fathead Minnow (Pimephales Promelas). Aquatic Toxicology, 204:107-116. 
Alsaadi, F. M., Madison, B. N., Brown, R. S., Hodson, P. V. and Langlois, V. S. (2018). Morphological and Molecular Effects of Two Diluted Bitumens on Developing Fathead Minnow (Pimephales Promelas). Aquatic Toxicology, 204:107-116.

Arukwe, A., Myburgh, J., Langberg, H. A., ... Moeder, M. (2016). Developmental alterations and endocrine-disruptive responses in farmed Nile Crocodiles (Crocodylus niloticus) exposed to Contaminants from the Crocodile River, South Africa. Aquatic Toxicology, 173: 83-93.

Arukwe, A., Røsbak R., Adeogun, A. O., ... Myburgh, J. (2015). Biotransformation and Oxidative Stress Responses in Captive Nile Crocodile (Crocodylus Niloticus) Exposed to Organic Contaminants from The Natural Environment in South Africa. Plos One, 10:1-19.

ATSDR (2015). The ATSDR 2015 Substance Priority List, Agency for Toxic Substances and Disease Registry, Division of Toxicology and Human Health Sciences, Atlanta, GA. DOI: http://www.atsdr.cdc.gov/spl/resources/atsdr_2015 spl detailed data table.pdf

ATSDR (Agency for Toxic Substances and Disease Registry), (1995). Toxicological Profile for Polycyclic Aromatic Hydrocarbons (PAHs), U.S. Department of Health and Human Services, Public Health Service, Agency for Toxic Substances and Disease Registry, Atlanta, GA.DOI: http://www.atsdr.cdc.gov/toxprofiles/tp69.pdf

ATSDR (Agency for Toxic Substances and Disease Registry), (2009). Case Studies in Environmental Medicine Toxicity of Polycyclic Aromatic Hydrocarbons (PAHs).US Department of Health and Human Services, retrieved from https://www.atsdr.cdc.gov/toxprofiles/tp69.pdf

ATSDR (Agency for Toxic Substances and Disease Registry), (2013). Polycyclic Aromatic Hydrocarbons (PAHs) Clinical Assessment. Environmental Health and Medicine Education Course: WB 1519. retrieved on $27^{\text {th }}$ November, 2019 from https://www.atsdr.cdc.gov/csem/csem.asp?csem=13 HYPERLINK "https://www.atsdr.cdc.gov/csem/csem.asp?csem=13\&po=12"\& HYPERLINK "https://www.atsdr.cdc.gov/csem/csem.asp?csem=13\&po=12"po=12

ATSDR (Agency for Toxic Substances and Disease Registry), (2017). Comprehensive environmental response, compensation, and liability act (CERCLA) priority list of hazardous substances. Retrieved from https://www.atsdr.cdc.gov/SPL/ on $25^{\text {th }}$ October, 2019

Babić J., Brankica, D. K., Snežana Š., ... Jelena M. P. (2018). Reduction of polycyclic aromatic hydrocarbons in common carp meat smoked in traditional conditions. Food Additives and Contaminants: Part B: 1939-3229. DOI: 10.1080/19393210.2018.14848 21.

Bani, M., Fukuhara, M., Kimura, M. and Ushio, F. (1998). Modulation of Snake Hepatic Cytochrome P450 by 3-Methylcholanthrene and Phenobarbital. Computational Biochemistry Physiology C. Toxicology Pharmacology, 119:1 43-148.

Beach, D. G., Quillian, M. A., Rouleau, C., Croll, R. P. and Hellou, J. (2010). Bioaccumulation and Biotransformation of Pyrene And 1-Hydroxypyrene By the Marine Whelk Buccinum Undatum. Environmental Toxicology and Chemistry, 29(4):779-88. DOI: $10.1002 /$ Etc. 112. 
Beyer, J., Jonsson, G., Porte, C., Krahn, M. M., and Ariese, F. (2010). Analytical Methods for Determining Metabolites of Polycyclic Aromatic Hydrocarbons (PAH) Pollutants in Fish Bile: Review. Environmental Toxicology Pharma cology, 30: 224-244.

Bosetti, C., Boffetta, P. and La-Vecchia, C. (2007). Occupational Exposures to Polycyclic Aromatic Hydrocarbons, and Respiratory and Urinary Tract Cancers: A Quantitative Review To 2005. Annals of Oncology, 18(3): 431-446.

Burchiel, S. W. and Luster, M. I. (2001). Signaling by Environmental Polycyclic Aromatic Hydrocarbons in Human Lymphocytes. Clinical Immunology, 98: 2-10. https://doi.org $\underline{10.1006 / \mathrm{clim} .2000 .4934 .}$

Campbell, L., Bower, D.S., Clulow, S., Stockwell, M., Clulow, J. and Mahony. M. (2019). Interaction Between Temperature and Sublethal Infection with The Amphibian Chytrid Fungus Impacts A Susceptible Frog Species. Science, 9: 1-8.

Campbell, L., Bower, D.S., Clulow, S., Stockwell, M., Clulow, J. and Mahony. M. (2019). Interaction Between Temperature and Sublethal Infection with The Amphibian Chytrid Fungus Impacts A Susceptible Frog Species. Science, 9: 1-8.

Campo, L., Rossella, F., Pavanello, S., ... Kapka, L. (2010). Urinary profiles to assess poly cyclic aromatic hydrocarbons exposure in coke-oven workers. Toxicology Letters, 192: $72-78$.

Chen, B. H. and Lin, Y. S. (1997). Formation of Polycyclic Aromatic Hydrocarbons during Processing of Duck Meat. Journal of Agricultural and Food Chemistry, 45: 1394-1403.

Copat, C., Grasso, A., Fiore, M., ... Signorelli, S. S. (2018). Trace elements in seafood from the Mediterranean Sea: An exposure risk assessment. Food and Chemical Toxicology, 115: 13-19. https://doi. org/10.1016/j.fct.2018.03.001.

Crain, D. A. and Guillette, L. J. (1998). Reptiles as Models of Contaminant Induced Endocrine Disruption. Animal Reproduction Science, 53:77-86.

Dey, S., Samanta, P., Mondal, N. S., Kole, D., Mandal, A., Patra, A., and Ghosh, A. R. (2019). Dose specific responses of Anabas testudineus (Bloch) to Anthracene (PAH): Haematological and Biochemical Manifestation. Emerging Contamin ants, 5: 232-239. http://www.fao.org/3/y 8705e/y8705e09.htm.

Diggs, D. L., Huderson, A. C., Harris, K. L., Myers, J. N., Banks, L. D. and Rekha-Devi, P.V. (2011). Polycyclic aromatic hydrocarbons and digestive tract cancers: a perspective. Journal of Environmental Science Health C. Environment Carcinogenesis Ecotoxicology. Rev., 29(4): 324-357. doi: 10.108 0/10590501.2011.629974.

Dighiesh, H. S., Eldanasoury, M. A., Kamel, S. A. and Sharaf S. M. (2019). Toxicity of WaterSoluble Fractions of Petroleum Crude Oil and its Histopathological Alterations Effects on Red Tilapia Fish. CATRINA, 18(1): 25-31.

Domingo, J. L. and Nadal, M. (2017). Carcinogenicity of Consumption of Red Meat and Processed Meat: A Review of Scientific News Since the IARC Decision. Food and Chemical Toxicology,105: 256-261, https://doi.org/10.1016/j.fct.20 17.04.028.

Dong, C. D., Chen, C. F. and Chen C. W. (2012). Determination of Polycyclic Aromatic Hydrocarbons in Industrial Harbor Sediments by GC-MS International Journal of Environmental Research in Public Health, 9: 2175-2188. 
Drwal, E., Rak, A. and Gregoraszczuk, E. L. (2019). Differential effects of ambient PAH mixtures on cellular and steroidogenic properties of placental JEG-3 and BeWo cells. Reproductive Toxicology, 86: 14-22. https://doi.org/10.1016/j.rep rotox.2019.03.003.

Duan, X., Shen, G., Yang, H., Tian, J., Wei, F., Gong, J. and Zhang, J. (2016). Dietary Intake Polycyclic Aromatic Hydrocarbons (PAHs) And Associated Cancer Risk in A Cohort of Chinese Urban Adults: Inter- and Intra-Individual Variability, Chemosphere, 144: 2469-2475, https://doi.org/10.1016/j.chemosphere.2015.11 .019.

Edwards, S. C., Jedrychowski, W., Butscher, M., ... Flak, E. (2010). Prenatal Exposure to Airborne Polycyclic Aromatic Hydrocarbons and Children's Intelligence At 5 Years of Age in A Prospective Cohort Study in Poland. Environmental Health Perspectives, 118(9): 1326-1331.

Erema R. D., Adaobi P. U. (2013). Polycyclic Aromatic Hydrocarbons in Sediment and Tissues of The Crab Callinectes Pallidus from The Azuabie Creek of The Upper Bonny Estuary in The Niger Delta. Research Journal of Applied Science, Engineering and Technology, 6: $2594-2600$.

ERG (Emergency Response Guidebook) (2016). U.S. Department of Transportation, Transport Canada, and Secretariat of Communications and Transport of Mexico, with collaboration from Argentina's Centro de Información Química para Emergencias. https://www.phmsa. dot.gov/hazmat/outreach-training/erg (accessed december 07, 2019).

Eze, S.O., Okoronkwo, N.E. and Egedeuzu, C.S. (2019). Assessment of Polycyclic Aromatic Hydrocarbons (PAHs) levels in selected roasted and smoked food samples. European Journal of Pure and Applied Chemistry, 6(1): 2398-1385

Fakolade, P. O., Ijiwade. E. O. and Adeniyi, A. P. (2017). Polycyclic Aromatic Hydrocarbon (PAHs) And Phenol's Status in Some Smoked Meat Products in Nigeria. Nigerian Journal of Animal Production, 44(4): 118-127.

Feuston, M. H., Hamilton, C. E. and Mackerer, C. R. (1996). Systemic and Developmental Toxicity of Dermally Applied Distillate Aromatic Extract in Rats. Fundamentals of Applied Toxicology, 30 (2): 276-284.

Feuston, M. H., Hamilton, C. E., Schreiner, C. A. and Mackerer (1997). C. R. Developmental Toxicity of Dermally Applied Crude Oils in Rats. Journal of Toxicology, Environment and Health, 52(1997): 79-93.

Feuston, M. H., Kerstetter, S. L., Singer, E. J. and Mehlman M. A. (1989). Developmental Toxicity of Clarified Slurry Oil Applied Dermally to Rats. Toxicology Induced Health, 3: 587-599.

Finch, B. E. and Stubblefield, W. A. (2019). Interactive Effects of Mixtures of Photo toxic PAHs. Bulletin of Environmental Contamination and Toxicology, 102: 168-174.

Gelboin, H. V., 1980. Benzo[a]pyrene Metabolism, Activation and Carcinogenesis: Role and Regulation of Mixed-Function Oxidases and Related Enzymes. Physiological Reviews, 60: $1107-1166$.

Ghasemzadeh-Mohammadi, V., Mohammadi, A., Hashemi, M., Khaksar, R. and Haratian, P. (2012). Microwave-Assisted Extraction and Dispersive Liquid-Liquid Microextraction Followed by Gas Chromatography-Mass Spectrometry for Isolation and Determination 
of Polycyclic Aromatic Hydrocarbons in Smoked fish. Journal of Chromatography A (1237): 30-36.

Gibbons, J. W., Scott, D. E., Ryan, T. J., ... Greene, J. L. (2000). The Global Decline of Reptiles and Amphibians. Bioscience, 50: 653-666.

Grung, M. (2016). PAH Related Effects on Fish in Sedimentation Ponds for Road Runoff and Potential Transfer of PAHs From Sediment to Biota. Science of The Total Environment, https://doi.org/10.1016/j.scitotenv.2016.05.191.

Guntupalli, S., Thunuguntla, V. B. S. C., Chalasani, L. M., Rao, C. V. and Bondili, J. S. (2019) Degradation and Metabolite Profiling of Benz (a) Anthracene, Dibenz (a, h) Anthracene and Indeno [1, 2, 3-cd] Pyrene by Aspergillus terricola, Polycyclic Aromatic Compounds, 39(1): 84-92. DOI: 10.1080/10406638.2016. 1262878.

Hailwood, M., King, D., Leoz, E., ... Pacyna, J. (2001). Ambient Air Pollution by Polycyclic Aromatic Hydrocarbons (PAH). Accessed $1^{\text {st }}$ May, 2019). http://ec.europa.eu/environ ment/archives/air/pdf/pp pah.pdf.

Haritash, A.K., Kaushik, C.P., (2009). Biodegradation aspects of polycyclic aromatic hydrocarbons (PAHs): A review. Journal of Hazardous Materials, 169: 1-15.

Harner, T., Rauert, C., Muir, D., ... Marson, G. (2018). Air Synthesis Review: Polycyclic Aromatic Compounds in The Oil Sands Region. Environmental Reviews, 468: 430468.

Hiba, A. M. (2015. Polycyclic Aromatic Hydrocarbons in Food Samples: Methods of Extraction. International Journal of Current Research, 7(12): 23603-23606.

Hitzel, A., Pohlmann, M., Schwagele, F., Speer, K. and Jira, W. (2013). "Polycyclic Aromatic Hydrocarbons (PAH) And Phenolic Substances in Meat Products Smoked with Different Types of Wood and Smoking Spices," Food Chemistry, 139(1): 955-962.

Huanling, W. U., Binghua, S. and Jinhua, L. (2019). Polycyclic Aromatic Hydrocarbons in Sediments/Soils of the Rapidly Urbanized Lower Reaches of the River Chaohu, China. International Journal of Environmental Research and Public Health, 16: 1613-2302. doi:10. 3390/ijerph16132302.

IARC (International Agency for Research on Cancer) (2018). List of Classifications, 1-123. https://monographs.iarc.fr/list-of-classifications-volumes (accessed 5-15 November 2019).

IARC (International Agency for Research on Cancer), (2019). Agents classified by the IARC monographs, volumes 1-123. Available at: https://monographs.iarc.fr/wpcontent/uploa ds/2018/09/ClassificationsAlphaOrder.pdf. (Accessed 3 May 2019)

IARC (International Agency for Research on Cancer), (2019). Agents classified by the IARC monographs, volumes 1-123. Available at: https://monographs.iarc.fr/wp content/uploads/2018/09/ClassificationsAlphaOrder.pdf. (Accessed 3 May 201 9)

IARC, (2010). IARC Monographs on the Evaluation of Carcinogenic Risks to Humans. Some Non-heterocyclic Polycyclic aromatic hydrocarbons and Some Related Exposures International Agency for Research on Cancer. Lyon, France. 92:1-853, Retrieved on $12^{\text {th }}$ April, 2019 from http://monographs.iarc.fr/ENG/Monog raphs/vol92/mono92.pdf. 
IARC, (2012). IARC Monographs on the Evaluation of Carcinogenic Risks to Humans. Chemical Agents and Related Occupations. Benzo[a]pyrene, International Agency for Research and Cancer, Lyon, France. 100F: 111-144. Retrieved on $12^{\text {th }}$ April, 2019 from http://monographs.iarc.fr/ENG/Monographs/vol100F/ mono100F-14.pdf.

Ijeoma, L., Ogbonna, P. and Effiong, I. D. (2015a). Effects of Various Methods of Singeing on The Heavy Metal, Proximate and Sensory Properties of Singed Cow Hide (Ponmo). Scholars Research Library, Archives of Applied Science Research, 7(4): 44-50.

Ijeoma, L., Princewill, O. and Kelechi B. N. (2015b). Determination of Levels of Polycyclic Aromatic Hydrocarbons on Singed Cow Hide (Punmo) and Charcoal Grilled Meat (Suya). Archives of Applied Science Research, 7 (4):1-6.

Ince, M. and Ince, K.O. (2019). An Overview the Toxicology of Benzo(a)pyrene as Biomarker for Human Health: A Mini-Review. Nov. Technology, Nutrition and Food Science, 4(2): 580-581. DOI: 10.31031/NTNF.2019.04.000581.

IPCS (International Programme on Chemical Safety), (2010). Polycyclic Aromatic Hydrocarbons, Selected Non-Heterocyclic Retrieved on 14 ${ }^{\text {th }}$ March, 2019 from http://www.inchem.org/documents/ehc/ehc/ ehc202. htm.

Jeng, H. A., Pan, C. H. and Chao, M. R. (2013).1-Hydroxypyrene as a Biomarker for Assessing the Effects of Exposure to Polycyclic Aromatic Hydrocarbons on Semen Quality and Sperm DNA Integrity. Journal of Environmental Science Health A. Toxicological Hazard Substance and Environment Engineering, 48(2): 8-152. DOI: 10.1080/03601234.2012.716741.

Kamankesh, M., Mohammadi, A., Hosseini, H. and Tehrani, Z. M. (2015). Rapid Determination of Polycyclic Aromatic Hydrocarbons in Grilled Meat Using Microwave-Assisted Extraction and Dispersive Liquid-Liquid Microextraction Coupled to Gas Chromatography-Mass Spectrometry. Meat Science, 103: 61-67.

Kamata, R., Nakajima, D. and Shiraishi, F. (2018). Agonistic Effects of Diverse Xenobiotics on The Constitutive Androstane Receptor as Detected in A Recombinant Yeast-Cell Assay. Toxicology in vitro, 46: 335-349, DOI: 10.1016/j.tiv.2017.09.014.

Kartalovic, B., Okanovic, D., Babic, J., Djordjevic, V., Jankovic, S. and Cirkovic, M. (2015). Polycyclic Aromatic Hydrocarbons in Smoked Ham. Procedia Food Science, 5: 144147.

Keith, L. H. (2015) The Source of U.S. EPA's Sixteen PAH Priority Pollutants, Polycyclic Aromatic Compounds, 35:2-4, 147-160, DOI: 10.1080/10406638.2014.892886.

Kim, K. H., Jahan, S. A., Kabir, E. and Brown, R. J. (2013). A Review of Airborne Polycyclic Aromatic Hydrocarbons and their Human Health Effects Environ ment International, 60: $71-80$.

Kuppusamy, S., Maddela, N. R., Megharaj, M. and Venkateswarlu, K. (2020). Total Petroleum Hydrocarbons: Environmental Fate, Toxicity, and Remediation. Springer Nature Switzerland, P. 157. https://doi.org/10.10074978-3-030-2403.

LaVoie, E. J., Hetcht, S. S., Amin, S., Bedenko, V. and Hoffmann, D. (1980). Identification of Mutagenic Dihydrodiols as Metabolites of Benzo(j) Fluoran thene and Benzo(k)Fluoranthene. Cancer Research, 40(12): 4528-32. 
Lawal, A. T. and Fantke, P. (2017). Polycyclic aromatic hydrocarbons: A review, Cog ent Environmental Science, 3:1. DOI: 10.1080/23311843.2017.1339841.

Ledesma, E., Rendueles, M. and Diaz, M. (2015). Spanish Smoked Meat Products: Benzo(a)Pyrene (Bap) Contamination and Moisture. Journal of Food Compo sition and Analysis, 37: 87-94.

Li, C., Li, C., Yu, H., ... Guo Y. (2020). Chemical Food Contaminants During Food Processing: Sources and Control. Critical Reviews in Food Science and Nutri tion, DOI: $\underline{10.1080 / 10408398.2020 .1762069 .}$

Lou, X. Y., Wu, P. R. and Guo, Y. (2019). Urinary Metabolites of Polycyclic Aromatic Hydrocarbons in Pregnant Women and Their Association with A Biomarker of Oxidative Stress. Environmental Science and Pollution Resources 26: 27281.

Madison, B. N., Hodson, P. V. and Langlois, V. S. (2015). Diluted Bitumen Causes Deformities and Molecular Responses Indicative of Oxidative Stress in Japanese Medaka Embryos. Aquatic Toxicology, 165: 222-230.

Mccarrick, S., Cunha, V., Zapletal, O., Vondráček, J. and Dreij, K. (2019). In Vitro And In Vivo Genotoxicity of Oxygenated Polycyclic Aromatic Hydrocarbons. Envi ronmental Pollution, 246: 678-687, https://doi.org/10.1016/j.envpol.2018. 12.092.

Meland, S., Gomes, T., Petersen, K., Håll, J., Lund, E., Kringstad, A. and Grung, M. (2019). Road Related Pollutants Induced DNA Damage in Dragonfly Nymphs (Odonata, anisoptera) Living in Highway Sedimentation Ponds. Scientific Reports, 9: 16002. https://doi.org/10.1038/s41598-019-52207-4.

Mirja, H., Ulla, L., Pirkko K., Tiina, R., Kimmo, P. and Marika, J. (2018). Critical Effects of Smoking Parameters on the Levels of Polycyclic Aromatic Hydrocarbons in Traditionally Smoked Fish and Meat Products in Finland. Hindawi Journal of Chemistry, 2018(2160958): 14. https://doi.org/10.1155/2018/2160958.

Mojiri, A., Zhou, J.L., Ohashi, A., Ozaki, N. and Kindaichi, T. (2019). Comprehensive Review of Polycyclic Aromatic Hydrocarbons in Water Sources, Their Effects and Treatments. Science of The Total Environment, 696(133971): 0048-9697.

Moorthy, B., Chu, C., Carlin, D.J., 2015. Polycyclic Aromatic Hydrocarbons: From Metabolism to Lung Cancer. Toxicological Sciences, 145: 5-15.

NCBI (National Centre for Biotechnology Information) (2019). PubChem Database. Acenaphthene, $\quad \mathrm{CID}=6734, \quad$ https://pubchem.ncbi.nlm.nih.gov/compound/Acen aphthene (accessed on Dec. 4, 2019).

NIOSH, (The National Institute for Occupational Safety and Health) (2019). Registry of Toxic Effect of Chemical Substances (RTECS), Retrieved on $4^{\text {th }}$ December, 2019 from https://www.cdc.gov/niosh-rtecs/CA8EAB70.html.

Nnaji, J. C. and Ekwe, N. P. (2018). Effect of Smoking on Polycyclic Aromatic Hydro carbons (PAHS) Concentrations in Catfish and Tilapia Muscles. Journal of Applied Science and Environmental Management, 22(2): 293 - 297.

NTP (National Toxicology Program) (1992). Institute of Environmental Health Sciences, National Institutes of Health. National Toxicology Program Chemical Repository Database. Research Triangle Park, North Carolina. 
Oranusi, S., Onibokun E. A., Obafemi, Y.D. and Dureke, G. (2018). Microbiology, Heterocyclic Amines and Polycyclic Aromatic Hydrocarbons Profiles of Some Grilled, Roasted and Smoked Foods in Lagos and Ogun States, Nigeria. African Journal of Food Science, 12(11): 336-346. DOI: 10.5897/AJFS2018.1737.

Parrott, J. L., Marentette, J. R., Hewitt, L. M., McMaster, M. E., Gillis, P. L., Norwood, W. P. and Kirk, J. L. (2018). Meltwater from Snow Contaminated by Oil Sands Emissions is Toxic to Larval Fish, but not Spring River Water. Science Total of the Environment, 625: $264-274$.

Parvez, F., Lauer, F. T., Factor-Litvak, P., Liu, X., Santella, R. M. and Islam, T. (2019). Assessment of Arsenic and Polycyclic Aromatic Hydrocarbon (PAH) Exposure s on Immune Function among Males in Bangladesh. PLoS ONE, 14(5): 0216662-0216662.

Patel, A. B., Shaikh, S., Jain, K. R., Desai, C. and Madamwar, D. (2020). Polycyclic Aromatic Hydrocarbons: Sources, Toxicity, and Remediation Approaches. Frontiers in microbiology, 11: 3389-562813.retrieved from https://doi.org/10.3389/fmicb.2020. $\underline{562813 .}$

Patterson, A. S. (2019). The Toxic Effects of Oil Sands Contaminants on Developing Amphibians (Master's dissertation). Queen's University Kingston, Ontario, Canada. Retrieved from https://qspace.library.queensu.ca/handle/1974/26510 ?show=full.

Peiffer, P., Cosnier, F., Grova, N., ... Cossec, B. (2013). Neurobehavioral Toxicity of a Repeated Exposure (14 Days) to the Airborne Polycyclic Aromatic Hydrocarbon Fluorene in Adult Wistar Male Rats. PLoS ONE, 8(8): e71413. https://doi.org/10.1371/journal.pone.0071413.

Peiffer, P., Cosnier, F., Grova, N., ... Cossec, B. (2013). Neurobehavioral Toxicity of a Repeated Exposure (14 Days) to the Airborne Polycyclic Aromatic Hydrocarbon Fluorene in Adult Wistar Male Rats. PLoS ONE, 8(8): e71413. https://doi.org/10.1371/journal.pone.0071413.

Perera, F., Tang, D., Whyatt, R., Lederman, S. A. and Jedrychowski, W. (2005). DNA Damage from Polycyclic Aromatic Hydrocarbons Measured by Benzo[a]Pyren e-DNA Adducts in Mothers and New-borns from Northern Manhattan, the World Trade Centre Area, Poland, and China. Cancer Epidemiology Biomarker s and Prevention, 14(3): 709-714.

Pessah, I. N., Beltzner, C., Burchiel, S. W., Sridhar, G., Penning, T. and Feng, W. (2001). A Bioactive Metabolite of Benzo[a]Pyrene, Benzo[a]Pyrene-7,8- Dione, Selectively Alters Microsomal $\mathrm{Ca}^{2+}$ Transport and Ryanodine Receptor Function. Molecular Pharmacology, 59: 506-513.

Pohanish, R. P. (2012). (ed). Sittig's Handbook of Toxic and Hazardous Chemical Carcinogens 6th Edition Volume 1: A-Vol. 2: L-Z. William Andrew, Waltham, MA 2012. P. 356.

Pott, P. (1775). Chirurgical Observations Relative to The Cataract, The Polypus of The Nose, The Cancer of The Scrotum, The Different Kinds of Ruptures, and the Mortification of the Toes and Feet, Printed, by TJ Carnegy, for L. Hawes, W. Clarke, and R. Collins, in Pater-noster row. P. 1714-1788, available at https://lib.ugent.be/catalog/rug01:001096666.

Pratt, M. M., John, K., Maclean, A. B., Afework, S., Philips, D. H. and Poirier M.C. (2011). Review Polycyclic Aromatic Hydrocarbon (PAH) Exposure and DNA Adduct Semi- 
Quantitation in Archived Human Tissues, International journal of Environmental Resources and Public health 8(7): 2675-2691; https://doi.org/ 10.3390/ijerph8072675.

Products, P., Yang, C., Wang, Z., Yang, Z., Hollebone, B., Brown, C.E., Landriault, M. et al. (2011). Chemical Fingerprints of Alberta Oil Sands and Related. Environmental Forensics, 12:173-188.

Romero, L. M. and Wikelski, M. (2002). Severe Effects of Low-Level Oil Contami nation on Wildlife Predicted by The Corticosterone-Stress Response: Prelimina ry Data and A Research Agenda. Spillage Science and Technology, 7:309-313.

Rossella, F., Campo, L., Pavanello, S., Kapka, L., Siwinska, E. and Fustinoni, S. (2009). Urinary Polycyclic Aromatic Hydrocarbons and Monohydroxy Metabolites as Biomarkers of Exposure in Coke Oven Workers. Occupational Environmental Medicine, 66(8): 509-16, DOI: 10.1136/oem.2008.042796.

Salman, J. M. and Kadhim, A. J. (2018). Evaluation PAHs in Agriculture Soil Samples Alkhacheya Site South of Baghdad, Iraq. Plant Archives, 18(1): 1005-1008.

Santos, P. M., Sánchez, M. N., Pavón, J. L. P. and Cordero, B. M. (2019). Determi nation of Polycyclic Aromatic Hydrocarbons in Human Biological Samples: A Critical Review. TrAC Trends in Analytical Chemistry, 133:194-209. https:// doi.org/10.1016/j.trac.2019.02.010.

Sanz-Lázaro, C., Marin, A. and Borredat, M. (2008) Toxicity Studies of Polynuclear Aromatic Hydrocarbons (PAHs) on European Amphipods. Toxicology Mecha nisms and Methods, 18: 323-327. DOI: 10.1080/15376510701380273.

Sanz-Lázaro, C., Marin, A. and Borredat, M. (2008) Toxicity Studies of Polynuclear Aromatic Hydrocarbons (PAHs) on European Amphipods. Toxicology Mecha nisms and Methods, 18: 323-327. DOI: 10.1080/15376510701380273.

Sarki, A. M. and Roni, B. L. (2019). This Disease Is "Not for Hospital": Myths and Misconceptions About Cancers in Northern Nigeria. Journal of Global Health Reports, 3. doi:10.29392/joghr.3.e2019070.

Sasikumar, M., Cheng P. and Jack, C. N. (2018). Genotoxicity Evaluation o.f MultiComponent Mixtures of Polycyclic Aromatic Hydrocarbons (PAHs), Arsenic, Cadmium, and Lead Using flow Cytometry-Based Micronucleus Test in HepG2 cells. Mutation Research, 16(30177-2): S1383-5718, DOI: https://doi.org/10. 1016/j.mrgentox.2018.01.002.

Schmoldt, A., Jacob, J. and Grimmer, G. (1981). Dose-Dependent Induction of Rat Liver Microsomal Aryl Hydrocarbon Monooxygenase by Benzo[k]Fluoranthe ne. Cancer Letter, 13(3): 249-57, DOI:10.1016/0304-3835(81)90025-2-.

Sepic, E., Bricelj, M. and Leskovsek, H. (2003). Toxicity of Fluoranthene and Its Biode gradation Metabolites to Aquatic Organisms. Chemosphere, 52(7): 1125-33 DOI:10.1016/S0045-6535(03)00321-7.

Sereshk, Z. H. and Bakhtiari, A. R. (2014). Distribution Patterns of PAHs in Different Tissues of Annulated Sea Snake (Hydrophis cyanocinctus) and Short Sea Snake (Lapemis curtus) from the Hara Protected Area on the North Coast of the Persian Gulf, Iran. Ecotoxicology Environmental Safety, 109: 116-123. 
Shimada, T., Takenaka, S., Murayama, N., Yamazaki, H., Kim, J. H. and Kim, D. (2015). Oxidation of Acenaphthene and Acenaphthylene by Human Cytochro me P450 Enzymes. Chemical Resource Toxicology, 16:28(2): 268-78. DOI:10. 1021/tx500505y.

Shimizu, T., Ding W. and Kameta, N. (2020). Soft-Matter Nanotubes: A Platform for Diverse Functions and Applications. Chemical Review, 120(4): 2347-2407, https://doi.org/10.1021/acs.chemrev.9b00509.

Siemiatycki, J. and Xu, M. (2019). Occupational Causes of Cancer. Bültmann, J. Siegrist (eds.), Handbook of Disability. Work and Health, Handbook Series in Occupational Health Sciences, 2:6-1. https://doi.org/10.1007/978-3-319-75381-2 6-1.

Silverman, D. T., Samanic, C. M., Lubin, J. H., ... Coble, J. B. (2012). The Diesel Exhaust in Miners, Study: A Nested Case Control Study of Lung Cancer and Diesel Exhaust. Journal of the National Cancer Institute, 104 (11): 855 - 68, doi:10.1093/jnci/djs034.

Smith, C. J. and Perfetti, T. A. (2019). An Approximated One-Quarter of IARCGroup 3 (Unclassifiable) Chemicals Fit More Appropriately into IARC Group 4(Probably not Carcinogenic). Toxicology Research and Application, 3: 1-10.

Soltani, N., Moore, F., Keshavarzi, B., Sorooshian, A. and Javid, R. (2019). Potentially Toxic Elements (Ptes) And Polycyclic Aromatic Hydrocarbons (PAHs) in Fish and Prawn in the Persian Gulf, Iran. Ecotoxicology and Environmental Safety, 173: 251-265.

Sparling, D.W., Linder, G., Bishop, C. A. and Krest, S. K. (2010). Recent advances in amphibian and reptile ecotoxicology. In Sparling, D.W., Linder, G., Bishop, C.A. and Krest, S.K., eds, Ecotoxicology of Amphibians and Reptiles, 2nd ed. CRC, Pensacola, FL, USA, pp 1-12. 4.

Stogiannidis, E. and Laane, R. (2015). Source Characterization of Polycyclic Aromatic Hydrocarbons by Using Their Molecular Indices: An Overview of Possibilities, in: Whitacre, D.M. (Ed.), Reviews of Environmental Contamination and Toxicology. Springer International Publishing, Cham, 49-133.

Sun, Y., Wu, S. and Gong, G. (2019). Trends of Research on Polycyclic Aromatic Hydrocarbons in Food: A 20-Year Perspective from 1997 to 2017. Trend in Food Science and Technology, 83: 86-98, https://doi.org/10.1016/j.tifs.2018.11.015.

Sunu N. E. (2013). Comparative Assessment of Heavy Metal Levels in Animal Hide Singed with Motor Vehicle Scrap Tyres and Liquefied Petroleum Gas (LPG) as Source of Fuel. (Master's dissertation). Kwame Nkrumah University of Science \& Technology, Kumasi, Ghana. Retrievd from http://ir.knust.edu.gh/xmlui/han dle/123456789/6699? show=full.

Tay, C. C., Talib, S. A., Alias, S. and Abidin, A. N. Z. (2017). Occurrence and Biorem ediation of Anthracene in the Environment. Journal of Fundamental and Appl ied Sciences, 9(6S): 214-226. doi:http://dx.doi.org/10.4314/jfas.v9i6s.17.

Tella, A. C., Ajayi, S. O., Abiola, B. E., Adekunle, A. K., Akintelu A. S., and Olabe miwo, O. M. (2017). Assessment of the Levels of Polycyclic Aromatic Hydro carbons in Wazo Market Topsoil, Ogbomoso, Nigeria. Ewemen Journal of Ana lytical \& Environmental Chemistry, 3(1): $111-118$.

Tran-Lam, T., Yen, H. D., Lien, K. N., Hoi, K., Ma, H. N. and Giang, T. L. (2018). Simultaneous Determination of 18 Polycyclic Aromatic Hydrocarbons in Daily Foods 
(Hanoi Metropolitan Area) by Gas Chromatography-Tandem Mass Spectrometry. Foods, 7: 120-201. doi:10.3390/foods7120201.

Trilecová, L., Krčková, S., Marvanová, S., ... Hulinková, P. (2011). Toxic Effects of Methylated Benzo[a]pyrenes in Rat Liver Stem-Like Cells. Machala. Chemical Research in Toxicology, 24(6): 866-876, DOI: 10.1021/tx200049x.

Uematsu, K. and Huggins, H. (1968). Induction of Leukemia and Ovarian Tumors in Mice by Pulse-Doses of Polycyclic Aromatic Hydrocarbons. Molecular Pharm acology, 4(5): 427-434.

Ulieme, R. E., Awer, S., Stagg, J.C., Yau, W. and Gato, W.E. (2019). The Hepatic Effects in Dams that Ingested 2-aminoanthracene during gestation and lactation. Toxicology and Industrial Health. https://doi.org/10.1177/0748233719875018.

Unwin, J., Cocker, J., Scobbie, E. and Chambers, H. (2006). An Assessment of Occu pational Exposure to Polycyclic Aromatic Hydrocarbons in the UK. Annals of Occupational Hygiene, 50(4): 395-403. DOI:10.1093/annhyg/mel0 10.

Vignet, C., Larcher, T., Davail, B., ... Lyphout, L. (2016). Fish Reproduction is Disru pted upon Lifelong Exposure to Environmental PAHs Fractions. Revealing Different Modes of Action. Toxics, 4-26.

Volkoff, S. J., Osterberg, J. S., ... Jayasundara, N. (2019). Embryonic Fundulus heteroc litus Responses to Sediment Extracts from Differentially Contaminated Sites in the Elizabeth River, VA. Ecotoxicology, 28: 02-116. https://doi.org/10.1007/ s10646-019$\underline{02116-\mathrm{z} .}$

Vonier, P. M., Crain, D. A., McLachlan, J. A., Guillette, L. J. and Arnold, S.F. (1996). Interaction of Environmental Chemicals with the Estrogen and Progesterone Receptors from the Oviduct of the American Alligator. Environmental Health Perspective. 104: $1318-1322$.

Wallace, S. J., de Solla, S. R., Thomas, P. J., Harner, T., Eng, A. and Langlois, V.S. (2018). Airborne Polycyclic Aromatic Compounds Contribute to The Induction of the TumourSuppressing P53 Pathway in Wild Double-Crested Cormorants. Ecotoxicological and Environmental Safety, 150:176-189.

Wassenberg, D. M. and Di Giulio, R. T. (2004). Synergistic Embryotoxicity Of Polycyclic Aromatic Hydrocarbon Aryl Hydrocarbon Receptor Agonists with Cytochrome P4501A Inhibitors in Fundulus heteroclitus. Environmental Health Perspective, 112(17): 1658-1664.

Whyte, J. J., Jung, R. E., Schmitt, C. J. and Tillitt, D. E. (2000). Ethoxyresorufin-o-deethylase (EROD) Activity in Fish as a Biomarker of Chemical Exposure. Critical Review in Toxicology. 30: 347-570.

Wolf, D. C., (2019). Physicochemical Properties and Toxicity of Polycyclic Aromatic Hydrocarbons (ed.). Effects of in situ Bioremediation Strategies on the Biodegradation of Polycyclic Aromatic Hydrocarbons and Microbial Comm unity Dynamics in Soil, a (doctoral thesis). University of California, Riverside, United State of America. Retrieved from https://escholarship.org/content/qt3 rb8663j/qt3rb8663j noSplash 03 a920494c07dc407c322980749a21ff.pdf. 
Wretling, S., Eriksson, A., Eskhult, G. A. and Larsson, B. (2010). Polycyclic Aromatic Hydrocarbons (PAHs) in Swedish Smoked Meat and Fish. Journal of Food Composition and Analysis, 23(3): 264-272.

Xia, Z., Duan, X., Qiu W., Liu D., Wang, B. and Tao, S. (2010). Health Risk Assess ment on Dietary Exposure to Polycyclic Aromatic Hydrocarbons (PAHs) in Taiyuan, China. Science of the Total Environment, 408: 5331- 5337.

Xia, Z., Duan, X., Qiu W., Liu D., Wang, B. and Tao, S. (2010). Health Risk Assess ment on Dietary Exposure to Polycyclic Aromatic Hydrocarbons (PAHs) in Taiyuan, China. Science of the Total Environment, 408: 5331- 5337.

Yang, J., Sun, p., Zhang, X., Wei, Huang, y., Du, W., Abdul Q. (2021). Source apportionment of PAHs in roadside agricultural soils of a megacity using positive matrix factorization receptor model and compound-specific carbon isotope analysis. Journal of Hazardous Materials, 403: 0304-3894. https://doi.org/10.1016/j.jhazmat.2020.123592.

Yaya, C., Soro, D. B., Aboua, K. N., Kouadio, D. L., Diarra, M., Ehouman, A. G., Meite, L. et al., (2019). Levels of contamination of meat and offal (skins) by polycyclic aromatic hydrocarbons during grid cooking or following pre-treatment of tire stripping. Journal of Chemical, Biological and Physical Sciences, 9(3): 372-379 DOI: 10.24214/jcbps.B.9.3.37279.

Zachara, A., Gałkowska, D. and Juszczak, L. (2017). Contamination of Smoked Meat and fish Products from Polish Market with Polycyclic Aromatic Hydrocarbons. Food Control, 80: $45-51$.

Zakaria, M. P., Takada, H., Tsutsumi, S., Ohno, K., Yamada, J., Kouno, E. and Kumata, H. (2002). Distribution of polycyclic aromatic hydrocarbons (PAHs) in rivers and estuaries in Malaysia: A widespread input of petrogenic PAHs. Environmental Science \& Technology, 36: 1907-1918.

Zhang, K., Zhang, B. Z., Li, S. M., ... Staebler, R. (2012a). Diurnal and Seasonal Variability in Size-Dependent Atmospheric Deposition Fluxes of Polycyclic Aromatic Hydrocarbons in an Urban Centre. Atmospheric Environment, 57: 41-48.

Zhang, Y., Tao, S., Shen, H. and Ma, J. (2009). Inhalation Exposure to Ambient Polycyclic Aromatic Hydrocarbons and Lung Cancer Risk of Chinese Population. Proceedings of the National Academy of Sciences, 106(50): 21063-21067.

Zhao, Z., Qin, Z., Cao, J. and Xia, L. (2017). Source and Ecologicla Risk Characteristics of PAHs in Sediment from Qinhuai River and Xuanwu lake, Nanjing, China. Journal of Chemistry, 2017: 18-96. https//doi.org/10.1155/2017/3510796.

Zhu, Y., Huang, H., Zhang, Y., ... Tao, T. (2021). Evaluation of PAHs in Edible Parts of Vegetables and their Human Health Risks in Jinzhong City, Shanxi Province, China: A Multimedia Modelling Approach. Science of the Total Environment, 773. https://doi.org/10.1016/j.scitotenv.2021 .145076.

Zungum, I. U., Imam, T. S., Ahmad, A. G., Abubakar, T., Benjamin, B., Daya, M. G. (2019). Impact of Typha Grass on Biodiversity Loss of Hadejia-Nguru Wetland Located between Jigawa and Yobe States of Nigeria: A Review. J. Appl. Sci. Environ. Manage. 23(10):1847-1853, DOI: https://dx.doi.org/10.4314/jasem.v23i10.13 
Zungum, I. U., Imam, T. S., Benjamin, B., Moisule, A., Daya, M. G., Abubakar, T., Bala, Z. M., Peter, D. D. (2020). In Vitro Assay of Bacterial Load on Some Ruminant Hide and Skin from North Western Nigeria. J. Appl. Sci. Environ. Manage. 24(8): 14251432, DOI:https://dx.doi.org/10.4314/jasem.v24i8.18

Zychowski, G. V. and Godard-codding, C. A. J. (2017). Reptilian Exposure to Polycyc lic Aromatic Hydrocarbons and Associated Effects: Critical Review. Environ mental Toxicology and Chemistry, 36(1):25-35. DOI:10.1002/etc.360 2. 